\title{
Effect of Foliar Application of Nutrients on Growth and Yield Attributing Characters of Black Gram
}

\author{
Basant Kumar Mandre ${ }^{1}$, R.P. Singh ${ }^{2}$, Megha Dubey ${ }^{2 *}$, Usha Waskle ${ }^{2}$ and Vinod Birla ${ }^{2}$ \\ ${ }^{1}$ FEO, ZARS, Powerkheda, J.N.K.V.V, Jabalpur, Madhya Pradesh, India \\ ${ }^{2}$ College of Agriculture, Sehore, J.N.K.V.V, Jabalpur, Madhya Pradesh, India \\ *Corresponding author
}

\section{Keywords}

Urea, Thiourea, TNAU plus wonder, blackgram, root nodules, RGR,CGR

\section{Article Info}

Accepted:

05 January 2020

Available Online:

10 February 2020

\section{A B S T R A C T}

An experiment was conducted to study the effect of foliar application of nutrients on growth and yield attributing characters of black gram under rain fed condition during kharif season 2015 at the research farm of AICRP on MULLaRP, R.A.K. College of Agriculture, Sehore (M.P.). The experiment was laid out in Randomized Block Design with three replications having eight treatments namely T1 [Control (water spray)], T2 [Urea 2\% spray at flowering], T3 [TNAU plus wonder @ $5 \mathrm{~kg} / \mathrm{ha}$ at flowering initiation], T4 [ Application of salicylic acid $75 \mathrm{ppm}$ at flower initiation and 7 days after first spray ], T5 [Application of 18:18:18 NPK 2\% at flower initiation], T6 [Application of $2 \%$ urea +salicylic acid spray at flower initiation], T7 [Application of Boron 0.25 ppm spray at flower initiation] and T8 [Application of Thiourea 500ppm spray at flower initiation stage]. Growth attributing characters i.e. plant height, branches/plant, root length, number and dry weight of root nodules, were significantly influenced with the different treatments and recorded higher values with the foliar application of 18:18:18 NPK $2 \%$ spray at flower initiation stage. Dry weight per plant was significantly influenced by different foliar nutrition and recorded higher value with application of 18:18:18 NPK 2\% spray at flowering. From this study it may be concluded that different treatments had positive effect on yield and growth of black gram. Application of 18:18:18 NPK $2 \%$ spray at flowering and 15 days later recorded maximum yield $(795 \mathrm{~kg} / \mathrm{ha})$, higher net return $(27288 /$ ha) with benefit cost ratio of 1:2.12.

\section{Introduction}

Blackgram is a widely grown grain legume and belongs to the family Fabaceae and assumes considerable importance from the point of food and nutritional security in the world. Urdbean grain contains about $25.21 \%$ protein, $60 \%$ carbohydrates, $1.64 \%$ fat (USDA nutrition resources). Urdbean is native of India and originated from Phaseolus sublobatus a wild plant. The pods are narrow, cylindrical and up to six cm long. The plant grows $30-100 \mathrm{~cm}$ with large hairy leaves and 4-6 cm seed pods. In India during 2014-15 urdbean was cultivated in $3.24 \mathrm{~m}$ ha with production of $1.52 \mathrm{mt}$ and productivity of 645 kg/ ha. In Madhya Pradesh, during 2014-15, the area was $0.39 \mathrm{~m}$ ha with annual 
production of $0.35 \mathrm{mt}$ and productivity 580 $\mathrm{kg} / \mathrm{ha}$ (Anonymous, 2014). Foliar application has been shown to avoid the problem of leaching-out in soils and prompts a quick reaction in the plant.

Of the micronutrients, foliar application of phosphorus, zinc and iron brings the greatest benefit in comparison with addition to soil where phosphorus becomes fixed in a form inaccessible to the plant and where zinc and iron are less available. Foliar fertilization (or foliar feeding) entails the application-via spraying of nutrients to plant leaves and stems and their absorption at those sites.

Used in both conventional and alternative production systems, it is a viable (though somewhat controversial) means of enhancing crop nutrition. Because information on conventional applications of foliar feeding is usually available through Cooperative Extension and the general farm press, this publication will stress applications in sustainable and organic agricultural systems.

Foliar feeding has been used as a means of supplying supplemental doses of minor and major nutrients, plant hormones, stimulants, and other beneficial substances. Observed effects of foliar fertilization have included yield increases, resistance to diseases and insect pests, improved drought tolerance, and enhanced crop quality. Plant response is dependent on species, fertilizer form, concentration, and frequency of application, as well as the stage of plant growth.

Potential of blackgram is very low because the fact that the crop is mainly grown in rainfed condition with poor management practices and also due to various physiological, biochemical as well as inherent factors associated with the crop, apart from the genetic makeup, the physiological factor viz., insufficient portioning assimilates, poor pod setting due to the flower abscission and lack of nutrients during critical stage of crop growth, coupled with harbor of disease and pest (Mahala et al., 2001) constitute the major constraints for the poor yield.. The productivity of blackgram in our country is very low.

Hence, there is need for enhancement of the productivity of blackgram by proper agronomic practices .One among them is foliar application of organic and inorganic sources of nutrients for exploiting genetic potential of the crop. This is considered to be an efficient and economic method of supplementing part of nutrients requirements at critical stages.

Foliar application is credited with the advantage of quick and efficient utilization of nutrients, elimination of losses through leaching, fixation and regulating the uptake of nutrients by plant (Manonmani and Srimathi, 2009).

\section{Materials and Methods}

The present experiment was laid out at research farm of R.A.K. College of Agriculture, Sehore (M.P.) during kharif season of 2015. The experimental area having fairly uniform topography, normal fertility status and the soil of the experiment field was medium black clay loam in texture fairly deep having a slight slope from west to east, which provides good drainage.

The experiment was laid out in a randomized complete block design with 8 treatments and each treatment was replicated three times. The Total No. of Plots were 24 with Gross plot size of $15.0 \mathrm{sq}$ meter and Net plot size of $10.80 \mathrm{sq}$ meter. Distance between plots was $0.5 \mathrm{~m}$, distance between replications was $1.0 \mathrm{~m}$, distance between rows was $30 \mathrm{~cm}$ and no. of rows/plot was 10 . 
Table.1 Influenced of foliar application of nutrients on growth parameters of Black gram

\begin{tabular}{|c|c|c|c|c|c|c|c|c|c|c|}
\hline \multirow[t]{2}{*}{ Treatments } & \multicolumn{2}{|c|}{$\begin{array}{c}\text { Plant } \\
\text { population } / \mathrm{m}^{2}\end{array}$} & \multicolumn{2}{|c|}{ Plant height (cm) } & \multicolumn{2}{|c|}{$\begin{array}{c}\text { Branches/plant } \\
\text { (No) }\end{array}$} & \multicolumn{2}{|c|}{$\begin{array}{c}\text { Root } \\
\text { length/plant }(\mathrm{cm})\end{array}$} & \multicolumn{2}{|c|}{$\begin{array}{c}\text { Root } \\
\text { nodules/plant } \\
\text { (No) }\end{array}$} \\
\hline & 30 DAS & $\begin{array}{l}\text { At } \\
\text { Maturity }\end{array}$ & $\begin{array}{c}45 \\
\text { DAS }\end{array}$ & $\begin{array}{c}\text { At } \\
\text { Maturity }\end{array}$ & $\begin{array}{c}45 \\
\text { DAS }\end{array}$ & $\begin{array}{c}\text { At } \\
\text { Maturity }\end{array}$ & 45 DAS & $\begin{array}{c}\text { 60 } \\
\text { DAS }\end{array}$ & 30 DAS & 45 DAS \\
\hline T1 & 27.28 & 26.15 & 32.38 & 40.07 & 3.15 & 4.03 & 10.76 & 13.07 & 10.33 & 11.30 \\
\hline $\mathbf{T} 2$ & 28.85 & 26.51 & 39.14 & 41.71 & 5.16 & 5.53 & 11.47 & 13.72 & 10.08 & 12.14 \\
\hline T3 & 27.48 & 26.38 & 40.07 & 50.15 & 4.37 & 5.42 & 11.41 & 15.22 & 11.74 & 14.75 \\
\hline $\mathbf{T 4}$ & 28.53 & 27.47 & 39.89 & 47.90 & 3.30 & 5.10 & 11.06 & 14.19 & 11.60 & 14.17 \\
\hline T5 & 28.68 & 28.55 & 42.67 & 53.99 & 4.78 & 6.08 & 13.73 & 16.39 & 11.71 & 15.22 \\
\hline T6 & 27.47 & 26.40 & 36.05 & 46.85 & 3.85 & 4.82 & 11.55 & 13.26 & 10.46 & 11.86 \\
\hline T7 & 26.96 & 26.31 & 34.74 & 45.94 & 3.98 & 5.02 & 11.29 & 12.94 & 11.02 & 11.41 \\
\hline T8 & 27.23 & 26.10 & 37.34 & 46.40 & 3.96 & 4.85 & 11.49 & 12.93 & 10.24 & 11.39 \\
\hline S.Em \pm & 0.96 & 0.37 & 1.68 & 1.91 & 0.21 & 0.35 & 0.49 & 0.63 & 0.63 & 0.69 \\
\hline C.D at $5 \%$ & NS & NS & 7.04 & 7.97 & 0.90 & 1.46 & 2.03 & 2.64 & NS & 2.90 \\
\hline
\end{tabular}

T1:Control ( water spray), T2:Urea $2 \%$ spray at flowering., T3:TNAU pulse wonder @ 5kg/ha at flowering initiation, T4: Salicylic acid $75 \mathrm{ppm}$ at flower initiation and 7 days after $1^{\text {st }}$ spray, T5:18:18:18 (NPK) $2 \%$ at flower initiation, T6: Urea $2 \%$ + salicylic acid spray at flower initiation, T7: Boron $0.25 \mathrm{ppm}$ spray at flower initiation, T8: Thiourea $500 \mathrm{ppm}$ spray at flower initiation, NS: Non-significant

The 8 treatments details is as follows: T1 : Control ( Application of water in the form of spray), T2 (Application of Urea 2\% spray at flowering stage), T3 ( Application of TNAU pulse wonder @ 5kg/ha at flowering initiation),T4 (Application of Salicylic acid $75 \mathrm{ppm}$ at flower initiation and 7 days after $1^{\text {st }}$ spray), T5 (Application of 18:18:18 (NPK) 2 $\%$ at flower initiation), T6 (Application of Urea 2\% + salicylic acid spray at flower initiation), T7 (Application of Boron $0.25 \mathrm{ppm}$ spray at flower initiation) and T8 (Application of Thiourea $500 \mathrm{ppm}$ spray at flower initiation).The variety AKU 96-3 was used in the experiment.

This variety is developed by cross with (PU 19) $x$ (NP 21) and developed at Dr. Panjabrao Deshmukh Krishi Vidyapeeth, Akola, (M.H.). It matures in 73 days. This variety is suitable for all the urd growing area of central zone of India for kharif season. It is resistant to yellow mosaic virus. The average grain yield is $10 \mathrm{q} / \mathrm{ha}$.

\section{Details of foliar nutrients}

\section{Urea}

Urea or Carbamide is an organic compound with the chemical formula $\mathrm{CO}\left(\mathrm{NH}_{2}\right)_{2}$.It is a colorless, odorless solid, highly soluble in water and practically non- toxic $\left(\mathrm{LD}_{50}\right.$ is 15 $\mathrm{g} / \mathrm{kg}$ for rat). Urea is widely used in fertilizer as a convenient source of nitrogen. Its nutrient composition is $46 \% \mathrm{~N}$.

\section{TNAU pulse wonder}

The department of Crop Physiology of Tamil Nadu Agricultural University (TNAU) Coimbatore has developed a crop booster to improve the yield potential of pulses. TNAU pulse wonder, as it is know, has been specifically designed to increase the yield of blackgram and greengram. This pulse wonder was developed by studying the physiological and nutritional disorders that occur in different stages of pulse crop. TNAU pulse 
wonder contains macro and micro nutrients and promotes better growth and development for the pulse crop. Apart from this, it has a lot of other advantages as well. It replaces the existing practise of diammonium phosphate foliar spray. TNAU pulse wonder is contains ingredients that are water soluble and facilitates complete absorption of nutrients. In addition to this, it is drought tolerant," said $\mathrm{S}$ Jeyaraman, director of crop management at TNAU. He further added that it reduces flower drops and improves the yield by 10-20 $\%$. To use the pulse wonder, mix it with 200 litres of water, for $2 \mathrm{~kg}$ per acre. This should be sprayed at the flowering stage.

\section{Salicylic acid}

Salicylic acid activates genes in some plants that produce chemicals that aid in the defense against pathogenic invaders. Salicylic acid contains $\mathrm{Ga}$ and IAA which promotes cell replication. Trade name of salicylic acid is aspirin. Salicylic acid (from Latin salix, willow tree, from the bark of which the substance used to be obtained) is a monohydroxybenzoic acid a type of phenolic acid and a beta hydroxy acid. This colorless crystalline organic acid is widely used in organic synthesis and functions as a plant hormone. It is derived from the metabolism of salicin.

\section{Liquid mix 18:18:18(NPK)}

18-18-18 mix is a balanced liquid N-P-K fertilizer, suitable for all crops, during all stages of plant growth. 18-18-18 mix liquid fertilizer provides an additional source of nitrogen, phosphorous and potassium during the growing season. 18-18-18 mix liquid fertilizer is in the form readily absorbed by plant tissue. 18-18-18 mix is manufactured by utilizing quality raw materials to provide a very agronomically efficient source of N-P-K. The quality of the raw materials used to formulate 18-18-18 mix maximized plant nutrient solubility.

Table.2 Influenced of foliar application of nutrients on dry matter production of Black gram

\begin{tabular}{|c|c|c|c|c|c|c|c|c|c|}
\hline \multirow[t]{2}{*}{ Treatments } & \multicolumn{2}{|c|}{$\begin{array}{l}\text { Dry weight of root } \\
\text { nodules/plant (mg) }\end{array}$} & \multicolumn{3}{|c|}{ Plant dry weight (g) } & \multicolumn{2}{|c|}{ CGR (g/m $\mathrm{m}^{2} /$ day $)$} & \multicolumn{2}{|c|}{ RGR (mg/g/day) } \\
\hline & 30 DAS & 45 DAS & $\begin{array}{c}\text { 30 } \\
\text { DAS }\end{array}$ & $\begin{array}{c}45 \\
\text { DAS }\end{array}$ & $\begin{array}{c}\text { 60 } \\
\text { DAS }\end{array}$ & $\begin{array}{c}\text { 30- } 45 \\
\text { DAS }\end{array}$ & $\begin{array}{l}45-60 \\
\text { DAS }\end{array}$ & $\begin{array}{c}\text { 30- } 45 \\
\text { DAS }\end{array}$ & $\begin{array}{l}45-60 \\
\text { DAS }\end{array}$ \\
\hline T1 & 2.02 & 11.45 & 3.37 & 4.01 & 9.27 & 1.42 & 12.01 & 0.0052 & 0.0242 \\
\hline T2 & 2.19 & 12.26 & 4.21 & 5.24 & 10.60 & 2.30 & 12.13 & 0.0042 & 0.0203 \\
\hline T3 & 2.78 & 14.20 & 4.08 & 6.12 & 12.84 & 4.53 & 15.03 & 0.0117 & 0.0214 \\
\hline T4 & 2.74 & 13.43 & 4.00 & 5.76 & 11.91 & 3.92 & 13.47 & 0.0105 & 0.0209 \\
\hline T5 & 2.62 & 14.39 & 4.12 & 6.82 & 13.63 & 6.00 & 16.87 & 0.0149 & 0.0197 \\
\hline T6 & 2.33 & 12.04 & 3.78 & 4.69 & 10.31 & 2.03 & 12.12 & 0.0179 & 0.0230 \\
\hline T7 & 2.12 & 11.58 & 3.65 & 4.42 & 10.07 & 1.48 & 14.30 & 0.0053 & .0238 \\
\hline T8 & 2.06 & 11.67 & 3.60 & 4.60 & 10.19 & 2.22 & 11.50 & 0.0070 & 0.0229 \\
\hline S.Em \pm & 0.19 & 0.62 & 0.22 & 0.21 & 0.57 & 0.67 & 0.63 & 0.0020 & 0.0017 \\
\hline C.D at $5 \%$ & NS & 2.59 & NS & 0.89 & 2.40 & 2.02 & 1.90 & 0.01 & NS \\
\hline
\end{tabular}

T1:Control (water spray), T2:Urea $2 \%$ spray at flowering., T3:TNAU pulse wonder @ 5kg/ha at flowering initiation, T4: Salicylic acid $75 \mathrm{ppm}$ at flower initiation and 7 days after $1^{\text {st }}$ spray, T5:18:18:18 (NPK) $2 \%$ at flower initiation, T6: Urea $2 \%$ + salicylic acid spray at flower initiation, T7: Boron $0.25 \mathrm{ppm}$ spray at flower initiation, T8: Thiourea $500 \mathrm{ppm}$ spray at flower initiation, NS: Non-significant 


\section{Boron}

The word boron was coined from borax, the mineral from which it was isolated, by analogy with carbon, which boron resembles chemically. The chemical behavior of boron resembles that of silicon more than aluminium. Crystalline boron is chemically inert and resistant to attack by boiling hydrofluoric or hydrochloric acid.

When finely divided, it is attacked slowly by hot concentrated hydrogen peroxide, hot concentrated nitric acid, hot sulfuric acid or hot mixture of sulfuric and chromic acids.

Boron is essential for all plant growth. It aids in the transfer of sugars and nutrients from leaves to reproductive organs, and increases pollination and seed development.

Borax, also known as sodium borate, sodium tetraborate, or disodium tetraborate, is an important boron compound, a mineral, and a salt of boric acid. Powdered borax is white, consisting of soft colorless crystals that dissolve easily in water.

\section{Thiourea solution}

Thiourea is an organosulfur compound with the formula $\mathrm{SC}\left(\mathrm{NH}_{2}\right)_{2}$. It is structurally similar to urea, except that the oxygen atom is replaced by a sulfur atom, but the properties of urea and thiourea differ significantly.

The data obtained on various parameters were tabulated and subjected to statistical analysis by the method suggested by Nichiporovich (1967).

The influence of treatment was tested with ' $F$ ' test wherever ' $F$ ' test shown their significance. The levels of treatment were compared by critical difference at $5 \%$ level of probability.

\section{Results and Discussion}

The results on "Foliar Application of Nutrients on Growth and Productivity of Blackgram has been examined and it was observed that foliar spray is a well-established tool to complete and enrich plant nutrition.

Foliar feeding can provide the nutrients needed for normal developments of crops in cases where absorption of nutrients from the soil is disturbed. As uptake of nutrients through the foliage is considerably faster than through roots, foliar sprays is also the method of choice when prompt correction of nutrient deficiencies is required.

Foliar application of nutrients influenced plant height of blackgram significantly over control. It was observed that the rate of growth in height was faster in the beginning up to 60 DAS, thereafter, it was slowed down. Nitrogen has been widely accepted as dominant growth promoter. The significant increase of plant height was due to the internodes elongation and the vigorous root growth.

The maximum height of the plant $(53.99 \mathrm{~cm})$ was obtained from foliar application of 18:18:18 (NPK) $2 \%$ at flower initiation (T5) as given in Table 1. Significant increase in plant height with foliar application can be attributed to the fact that micronutrients enhance plant vigour and strengthen the stalk (Das, 1999).

During this study it was examined that these results also resemble the findings of Barik et al.,(1994) who reported increase in plant height with foliar application of nutrients. The number of branches per plant was significantly higher with the application of 18:18:18 (NPK) $2 \%$ at flower initiation $\left(\mathrm{T}_{5}\right)$. The increase in branches per plant due to the twice application of NPK, which helped in 
acceleration of various metabolic process viz. photosynthesis, energy transfer reaction and symbiotic biological $\mathrm{N}$ - fixation process. More number of branches and plant height might be due to the more availability of nitrogen and phosphorus (18:18;18 NPK), which plays a vital role in cell division.

The application of 18:18:18 (NPK) $2 \%$ at flower initiation $\left(T_{5}\right)$ at 60 DAS recorded highest root length (16.39), which was significantly superior to rest of the treatments except $\left(\mathrm{T}_{3}\right)$ as given in Table 1. At 60 days after sowing, application of 18:18:18 (NPK) 2 $\%$ at flower initiation (T5) was recorded highest dry matter production (13.63g) per plant, which was significantly better than all other treatments.

The significant increase of dry weight/plant was due to the fact that nitrogen helps in maintaining higher auxin level which might have resulted in better plant height, leaf area and presumably chlorophyll content of the leaves. This might have resulted into better interception, absorption and utilization of radian energy, leading to higher photosynthetic rate and finally more accumulation of dry matter by the plants.

Bera et al.,(2008) reported that the significant increase in growth characters of black gram might be due to combination of foliar application of nutrient and growth regulator which play a major role in growth development and metabolism of black gram.

Maximum number of root nodules were recorded by the application of 18:18:18 (NPK) $2 \%$ at flower initiation (T5), which might be because of nitrogen and phosphorus influenced the better root development of the plant and it might profuse nodulation on account of increase in the rhizobial activity in the rhizosphere under the influence of foliar nutrition of $2 \%$ 18:18:18 (NPK), which in turn resulted in the formation of active and more number of nodules. Geetha and Velayutham (2009) results revealed that all the growth parameters, NPK uptake and yield were significantly influenced when foliar spray of $2 \% \mathrm{DAP}+1 \% \mathrm{KCl}$ was given at flowering and pod filling stages of crop growth.

Interaction between fertilizer application and foliar spray was significant for growth parameters, dry mater production (DMP), and yield. Application of 18:18:18 (NPK) $2 \%$ at flower initiation (T5), produced maximum CGR $\left(16.87 \mathrm{~g} / \mathrm{m}^{2} /\right.$ day $)$ followed by application of TNAU pulse wonder @ 5kg/ha at flowering initiation $\left(T_{3}\right)\left(15.03 \mathrm{~g} / \mathrm{m}^{2} /\right.$ day $)$ at 45 -60 days interval. Application of Boron $0.25 \mathrm{ppm}$ spray at flower initiation $\left(\mathrm{T}_{7}\right)$ produced maximum RGR $(0.0238 \mathrm{mg} / \mathrm{g} / \mathrm{day})$ at $45-60$ days interval as given Table 2 .

Lolesh pegu et al.,(2011)) found that foliar application of $100 \mathrm{ppm}$ boron at 20 and 45 DAS significant variation in root parameter physiological and biochemical parameters .Number of pods plant ${ }^{-1}$ is an important yield component in blackgram and the treatments viz., urea, TNAU pulse wonder, salicylic acid increased the number of pods plant ${ }^{-1}$.

However, foliar spray of 18:18:18 (NPK) $2 \%$ at flower initiation of crop growth resulted in significantly higher number of pods plant ${ }^{-1}$ (16.34) than other foliar spray treatments (Table 3). The foliar application of nutrients through 2\% 18:18:18 NPK at flower initiation and pod formation stage might have reduced flower drop.

This might have significantly increased the number of pods plant ${ }^{-1}$ as also reported by Growada and Growada (1980) that the number of pods per plant was increased with foliar application of NPK in mungbean and black gram. It will decreased the flower drop 
due to prolonged assimilatory activity of leaves might be another possible reason for higher number of pods plant ${ }^{-1}$. Further, the foliage applied nitrogen and phosphorus at the initial stages might have been effectively absorbed and translocated to the pods resulting in more number of pods plant ${ }^{-1}$. The results obtained by Solaiappan et al.,(2002) in redgram are concomitant to the present finding.

Foliar application of 2\% 18:18:18 NPK twice at flower initiation and pod formation stages of crop growth significantly influenced the number of seeds pod $^{-1}$ and 100 seed weight. Foliar application of 18:18:18 (NPK) $2 \%$ at flower initiation $\left(\mathrm{T}_{5}\right)$ produced maximum seed per pod (5.90) which was statistically at par with treatments $\mathrm{T}_{3}, \mathrm{~T}_{6}, \mathrm{~T}_{4}$ and $\mathrm{T}_{2}$ and significantly superior than rest of the treatments.
Azarpour et al.,(2011) reported that the effect of foliar spray on cowpea plants with humic acid at the concentration of $50 \mathrm{mg}$ per liter in presence of the nitrogen fertilizer $(45 \mathrm{~kg}$ per hectare) produced the highest values of seed yield, number of pods per plants, number of seeds per pod, pod length, seed length and seed width. Hamid (1991) reported that foliar application of nitrogen increased seed number per pod in mungbean.

Foliar application of different nutrients had significant variation in the seed yield of blackgram. Among the treatments, foliar application of 18:18:18 (NPK) $2 \%$ at flower initiation $\left(\mathrm{T}_{5}\right)$ recorded significantly higher seed yield (795 kg ha-1). It was comparable with TNAU pulse wonder @ 5kg/ha at flowering initiation $\left(\mathrm{T}_{3}\right)$ and Boron $0.25 \mathrm{ppm}$ spray at flower initiation( $\left.\mathrm{T}_{7}\right)$ as given in Table 3.

Table.3 Influenced of foliar application of nutrients on yield attributing characters of Black gram

\begin{tabular}{|l|l|l|l|l|l|l|l|}
\hline $\begin{array}{l}\text { Treatme } \\
\text { nts }\end{array}$ & $\begin{array}{l}\text { Pods } \\
\text { /plant (no) }\end{array}$ & $\begin{array}{l}\text { Seeds } \\
\text { /pod (no) }\end{array}$ & $\begin{array}{l}\text { Grain } \\
\text { yield } \\
\text { /plant }(\mathbf{g})\end{array}$ & $\begin{array}{l}\text { Seed index } \\
\text { (g) }\end{array}$ & $\begin{array}{l}\text { Seed yield } \\
\text { (kg/ha) }\end{array}$ & $\begin{array}{l}\text { Straw } \\
\text { yield } \\
\text { (kg/ha) }\end{array}$ & $\begin{array}{l}\text { Harvest } \\
\text { index }(\%)\end{array}$ \\
\hline T1 & 10.81 & 4.11 & 1.91 & 4.33 & 426.00 & 688.00 & 38.12 \\
\hline T2 & 14.61 & 5.03 & 3.41 & 4.60 & 560.00 & 973.00 & 36.51 \\
\hline T3 & 15.79 & 5.16 & 3.87 & 4.55 & 653.00 & 1130.0 & 36.70 \\
\hline T4 & 15.31 & 5.07 & 2.39 & 4.37 & 637.00 & 1065.0 & 37.41 \\
\hline T5 & 16.34 & 5.90 & 4.47 & 5.45 & 795.00 & 1290.0 & 38.13 \\
\hline T6 & 14.08 & 5.09 & 3.24 & 4.47 & 582.00 & 983.00 & 37.18 \\
\hline T7 & 13.62 & 4.86 & 3.03 & 4.63 & 650.00 & 1145.0 & 36.21 \\
\hline T8 & 14.31 & 4.68 & 2.94 & 4.45 & 560.00 & 987.00 & 36.42 \\
\hline S.Em \pm & 0.70 & 0.22 & 0.18 & 0.21 & 20.06 & 44.30 & 1.36 \\
\hline $\begin{array}{l}\text { C.D at } \\
\text { 5\% }\end{array}$ & 2.92 & 0.93 & 0.76 & 0.89 & 83.94 & 185.43 & NS \\
\hline
\end{tabular}

T1:Control ( water spray), T2:Urea $2 \%$ spray at flowering., T3:TNAU pulse wonder @ 5kg/ha at flowering initiation, T4: Salicylic acid $75 \mathrm{ppm}$ at flower initiation and 7 days after $1^{\text {st }}$ spray, T5:18:18:18 (NPK) $2 \%$ at flower initiation, T6: Urea 2\% + salicylic acid spray at flower initiation, T7: Boron $0.25 \mathrm{ppm}$ spray at flower initiation, T8: Thiourea 500 ppm spray at flower initiation, NS: Non-significant 
Kumaran and Subramanian (2001) reported that grain and straw yield (1116 and $3351 \mathrm{~kg} \mathrm{ha}^{-1}$, respectively) was recorded higher in application of $100 \%$ recommended dose of NPK + DAP 2\% + TNAU pulse wonder $5.0 \mathrm{~kg} \mathrm{ha}^{-1 .}$ Pandey and Gupta (2013) reported that the foliar application of boron increased the yield parameters like number of pods, pod size and number of seeds formed per plant, it also improved the seed yield and seed quality in black gram.

The increase in straw yield is directly related mainly to increase in the vegetative growth of the plant. Application of 18:18:18 (NPK) $2 \%$ at flower initiation produced highest straw yield, which was at par with application of 19 Boron $0.25 \mathrm{ppm}$ spray at flower initiation (T7) and significantly higher than remaining treatments. It was mainly due to the maximum plant height and CGR. The analysis of variance for harvest index reveals that the effect of foliar application of nutrients on harvest index was found non- significant. The maximum harvest index was recorded with the foliar application of 18:18:18 (NPK) $2 \%$ at flower initiation.

This might be because nitrogen and phosphorus are responsible in influencing the yield attributing characters like pods per plant and seeds per pod, which ultimately influenced the grain yield and hence harvest index increased. Foliar spray of 18:18:18 (NPK) $2 \%$ at flower initiation crop growth recorded higher gross returns (Rs. 51570) and net returns (Rs27288) followed by foliar spray of TNAU pulse wonder @ $5 \mathrm{~kg} / \mathrm{ha}$ at flowering initiation crop growth with gross returns of Rs 42589.8 and net returns of Rs. 19107.8 Water spray treatment (control) recorded the least gross returns (Rs. 27605.19) and net returns (Rs. 5123.19). Similarly, foliar application of 18:18:18 (NPK) $2 \%$ at flower initiation of crop growth registered higher $\mathrm{B}: \mathrm{C}$ ratio (2.12) followed by foliar spray of TNAU pulse wonder @ 5kg/ha at flowering initiation $\left(\mathrm{T}_{3}\right)$ stages of crop growth (1.81) and the lowest B:C ratio (1.22) was recorded under the water spray treatment.

Table.4 Economics of the various treatments

\begin{tabular}{|l|c|c|c|c|c|c|}
\hline $\begin{array}{c}\text { Treatment } \\
\mathbf{S}\end{array}$ & $\begin{array}{c}\text { Grain } \\
\text { yield } \\
\text { (kg/ha) }\end{array}$ & $\begin{array}{c}\text { Straw } \\
\text { yield } \\
\text { (kg/ha) }\end{array}$ & $\begin{array}{c}\text { Gross } \\
\text { return } \\
\text { (₹/ha) }\end{array}$ & $\begin{array}{c}\text { Cost of } \\
\text { cultivation } \\
\text { (₹/ha) }\end{array}$ & $\begin{array}{c}\text { Net profit } \\
\text { (₹/ha) }\end{array}$ & $\begin{array}{c}\text { Benefit : cost } \\
\text { ratio } \\
\text { (Per } \\
\text { ₹invested) }\end{array}$ \\
\hline T1 & 426.00 & 683.00 & 27605.19 & 22482 & 5123.20 & $1: 1.22$ \\
\hline T2 & 560.00 & 973.00 & 36519.99 & 22552 & 13967.90 & $1: 1.61$ \\
\hline T3 & 653.00 & 1130.00 & 42589.80 & 23482 & 19107.80 & $1: 1.81$ \\
\hline T4 & 637.00 & 1065.00 & 41395.20 & 23682 & 17713.20 & $1: 1.74$ \\
\hline T5 & 795.00 & 1290.00 & 51570.00 & 24282 & 27288.00 & $1: 2.12$ \\
\hline T6 & 582.00 & 983.00 & 37869.90 & 23548 & 14321.90 & $1: 1.60$ \\
\hline T7 & 650.00 & 1145.00 & 42435.00 & 23582 & 18853.00 & $1: 1.79$ \\
\hline T8 & 560.00 & 987.00 & 36560.01 & 23222 & 13338.01 & $1: 1.57$ \\
\hline
\end{tabular}

T1:Control ( water spray), T2:Urea 2\% spray at flowering., T3:TNAU pulse wonder @ 5kg/ha at flowering initiation, T4: Salicylic acid $75 \mathrm{ppm}$ at flower initiation and 7 days after $1^{\text {st }}$ spray, T5:18:18:18 (NPK) $2 \%$ at flower initiation, T6: Urea $2 \%$ + salicylic acid spray at flower initiation, T7: Boron $0.25 \mathrm{ppm}$ spray at flower initiation, T8: Thiourea 500 ppm spray at flower initiation, NS: Non-significant 
Similar result of improvement in the grain yield and net income with high $\mathrm{B}: \mathrm{C}$ ratio due to foliar applications of 18:18:18 (NPK) $2 \%$ has been reported earlier by Chandrasekhar and Bangarusamy (2003), Marimuthu and Surendran (2015) reported that application of $100 \%$ recommended dose of $\mathrm{NPK}+\mathrm{DAP}$ $2 \%+$ TNAU pulse wonder $5.0 \mathrm{~kg} \mathrm{ha}^{-1}$ was recorded significantly higher plant height $(37.62 \mathrm{~cm})$, number of pods / plant $(37.15)$, yield of black gram $\left(1162 \mathrm{~kg} \mathrm{ha}^{-1}\right)$, and benefit cost ratio (2.98) over the other treatments. The lowest black gram yield $\left(730 \mathrm{~kg} \mathrm{ha}^{-1}\right)$ was recorded in control as given in Table 4.

Application of 18:18:1 NPK 2\% at flower initiation stage resulted in increased growth and yield attributing characters in black gram. The treatment resulted in increased plant height $(53.99 \mathrm{~cm})$,branches/plant (6.08), root length (16.39),root nodules/plant(15.22),pods /plant (16.34), seeds/pod (5.90), grain yield/plant (4.47 g),seed index(5.45), seed yield $(795 \mathrm{~kg})$,straw yield $(1290 \mathrm{~kg})$ and harvest index (38.13).

The maximum gross monetary return of Rs 51570 and benefit: cost ratio of 1:2.12 was obtained .Therefore foliar application of nutrients can be taken as a substitute for improving plant growth and yield of black gram.

\section{References}

Anonymouus (2014). Annual report of All India Co-ordinated Research Project on MuLLaRP , Kanpur. Pp: 26-28

Azarpour, E., Danesh, R. K., Mohammadi, S., Bozorgi, H. R., and Moraditochaee. (2011) Effect of nitrogen fertilizer under foliar spraying of humic acid an yield and yield components of cow pea (Vigna unguiculata). World Applied Science Journal 13:1445-1449
Barik A, Jana P.K, Sunda J and Mukherjee A.K (1994). Influence of nitrogen, phosphorus and potash fertilization on growth, yield and oil of Kharif groundnut. Indian Journal of Agricultural Sciences, 38(2): 105-111

Bera ,A.K., Maity, U., and Maumdar, D. (2008). Effect of foliar application of brassinilide and salicylic acid on NPK content in leaf and nutritive values of seed in greengram. Legume Research, 31(2), 169-173

Chandrasekar ,C.N. and Bangarusamy,U.( 2003). Maximizing the yield of mungbean by foliar application of growth regulating chemicals and nutrients. Madras Agric. J. 90 (1-3): 142-145.

Das, P.C. (1999). Plants Nutrients. In: Manures and Fertilizers. 2nd Edition. Kalyani Publishers, New Dehli, India, pp: $5-10$

Geetha, P. and Velayutham, A. (2009). Refinement of nutrient management techniques for growth, yield and nutrient uptake of rice fallow blackgram. Madras Agricultural Journal; 96(1/6):163-166.

Growada,S. T., and Growada, K. T. K., (1980). Influence of fertilization yield component of green gram . Ind. Journal of Agronomy. 23.(4):374

Hamid,(1991) Foliar application of nitrogen in mungbean. Annuals Bangladesh Agriculture.1(1) :33-39

Kumaran, S., and Subramanian, M. (2001). Effect of plant population and methods of nutrient application on yield and economics of blackgram. Research on Crops, 2(1), 320-322.

Mahala, C.P.S., Dadheech, R.C. and Kulhari, R.K., (2001). Effect of plant growth regulators and yield of Black gram at varying levels of phosphorus . Crop Research ., 18 (1) : 163-165.

Manonmani, V. and Srimathi, P. (2009). 
Influence of mother crop nutrition on seed and quality of balckgram. Madras Agriculture Journal., 96 (16): 125128.

Marimuthu,S. and Surendran,U.(2015) .Effect of nutrients and plant growth regulators on growth and yield of black gram in sandy loam soils of Cauvery new delta zone, India. Cogent Food and Agriculture :2-9

Nichiporovich, A.A. (1967). Aims of research on the photosynthesis of plant as a factor of production (In) Nichiporovich, A.A. (Ed.) photosynthesis productive system programme for science translation, Jerusaleum Israel 3 (36).
Pandey, N. and Gupta, B. (2013). The impact of foliar Boron sprays on reproductive biology and seed quality of black gram. Journal of .Traditional Elemental Medicine Biology. 27(1): 58-64.

Pegu. Lolesh., Kalita., Das .P., Koushik. ,Alam.S, and Dekabarua. H.R (2011) Performance of boron in black gram .Legume Research 36(6) 505-510

Solaiappan, U. and Ramiah,S.(2002). Effect of seed treatments, soil and foliar fertilization on $\mathrm{N}$ and $\mathrm{P}$ on yield attributes of pigeon pea grown under rainfed condition. Indian Journal of Agronomy., 35 (3): 234-237.

\section{How to cite this article:}

Basant Kumar Mandre, R.P. Singh, Megha Dubey, Usha Waskle and Vinod Birla. 2020. Effect of Foliar Application of Nutrients on Growth and Yield Attributing Characters of Black Gram. Int.J.Curr.Microbiol.App.Sci. 9(02): 419-428. doi: https://doi.org/10.20546/ijcmas.2020.902.052 